\title{
As Crônicas de Fernando Fernandez
}

Renata Oliveira de Souza ${ }^{1}$

\section{BоOK REVIEW}

Fernando Fernandez. Os Mastodontes de Barriga Cheia e Outras Histórias - Crônicas de Biologia e Conservação da Natureza. 1. ed. Rio de Janeiro: Technical Books. 2016. 279 páginas. ISBN: 978-85-61368-53-1.

O ecólogo e paleontólogo Fernando Fernandez (n. 1961) obteve um Ph. D. em Ecologia pela Durham University (Inglaterra). Atualmente, é professor da Universidade Federal do Rio de Janeiro. Por meio de importantes publicações, como a de seu primeiro livro, "O Poema Imperfeito", que foi um dos maiores sucessos editoriais brasileiros sobre conservação da natureza, Fernandez tem dado grandes contribuições científicas nos campos da ecologia de populações, da biologia da conservação e da paleoecologia.

\footnotetext{
1 Doutorado em Desenvolvimento Sustentável (Centro de Desenvolvimento Sustentável, Universidade de Brasília), Brasil. ORCID: 0000-0002-8881-6439. renataros@hotmail.com

2 Fernandez, Fernando, O Poema Imperfeito Crônicas de Biologia, Conservação da Natureza e Seus Heróis (UFPR, 2011)
} 
O livro "Os Mastodontes de Barriga Cheia e Outras Histórias - Crônicas de Biologia e Conservação da Natureza", publicado em 2016, é uma coletânea que traz uma série de 30 crônicas que Fernandez escreveu para o site "O Eco" (https://www.oeco.org.br/), do qual ele é o Presidente do Conselho de Administração. Os textos têm como temática central a biologia e a conservação da natureza com ramificações para as mais diversas áreas, como paleontologia, evolução, ecologia, literatura, cinema, sustentabilidade e muitas outras.

O título do livro faz referência ao primeiro texto da obra, que conta o caso dos mastodontes de barriga cheia, cujos restos dos chamados mastodontes norteamericanos datados de 9.900 anos foram escavados em solos congelados da região dos Grandes Lagos, pelo paleontólogo Dan Fisher, considerando o maior especialista do mundo em presas de elefantes fósseis. A pesquisa demostrou, por meio de análise das presas das elefantas, que os mastodontes estavam se reproduzindo normalmente, diferente do que aconteceria se elas estivessem sofrendo com graves mudanças climáticas. Dessa forma, a sua extinção nada teve a ver com alteração das condições ambientais durante o Quaternário, como sugerem alguns, e sim com a aparição dos seres humanos na vida desses animais, que o caçaram até a extinção.

Este primeiro texto mostra aspectos que estamos vivendo atualmente em relação aos problemas ambientais. Trata-se de um acontecimento de extinção na qual preferimos ignorar ou até negar a participação humana, apesar das muitas evidencias dela. Assim acontece com muitos outros eventos ambientais catastróficos em relação aos quais, por receio de ter que sair de suas zonas de conforto, a humanidade está optando por se esquivar da responsabilidade.

A mesma observação quanto a essa atitude de negação pode ser observada em outros textos reunidos no livro, como "Nunca é por causa da demografia" (p. 105), que discorre sobre como se evita falar a respeito da demografia como responsável por vários problemas sociais e ambientais. O autor faz alguns relatos de como o crescimento demográfico exponencial, como o acontecido no pós-Segunda Guerra Mundial, acarretou sérios problemas sociais como miséria, fome e desigualdade. Apesar de terem havido alguns alertas bem alarmantes, como o de Paul Ehrlich, em 
“The Population Bomb" ${ }^{3}$, a questão demográfica e os seus efeitos sociais e ambientais rapidamente voltaram a ser desprezados.

Sob uma óptica mais prática, o livro traz textos mais otimistas, como "Preenchendo com vida a floresta vazia" (p. 112) e "Os ursos de Răcădău e a esperança" (p. 203) os quais o autor dá esperança de reversão da problemática ambiental. No primeiro, Fernandez discorre sobre métodos propostos para a recuperação da biodiversidade perdida. Como o "Pleistocene rewilding" ${ }^{4}$ de Josh Donlan, que sugere a introdução de uma fauna de grandes vertebrados aparentados das espécies extintas na América do Norte até o final do Pleistoceno. Outro método, sugerido pelo próprio autor e o seu colega Luiz Gustavo Oliveira-Santos, seria a "refaunação" de florestas vazias, para repor extinções locais e recentes. Nesse método a restauração seria de faunas inteiras, por meio da reintrodução de conjuntos de espécies nativas em ecossistemas dos quais elas foram localmente extintas. A sugestão de Fernandez é introduzir a técnica de "refaunação" na agenda para a conservação do século XXI.

Como cientista ambiental, assim que comecei a ler sobre a "refaunação" de Fernandez, me veio à mente os diversos desafios que esse método enfrentaria para atingir o seu propósito sem causar novos problemas ambientais. No entanto, ao final da leitura, passei a ver essa proposta como uma possibilidade válida para tentar reverter a crise de perda de biodiversidade em situações específicas nas quais essa técnica poderia ser implantada. Ripple \& Beschta $(2012)^{5}$, mostra como a reintrodução de uma espécie recuperou um ambiente. Nesse trabalho, apesar de não ter sido reintroduzidos conjuntos inteiros de espécies nativas, a reintrodução de uma, o lobo, já foi suficiente pra gerar um grande impacto positivo naquele hábitat.

Quanto a outra manifestação de otimismo do autor, em "Os ursos de Răcădău e a esperança" (p. 203), ele trata de uma passagem do livro "A canção do Dôdo" de David Quammen que conta o caso de um condomínio da classe média baixa chamado Răcădău localizado na periferia da cidade romena de Brasov. O local é cercado por

\footnotetext{
3 Paul R. Ehrlich, The Population Bomb (Buccaneer Books, 1995)

${ }^{4} \mathrm{C}$. Josh Donlan et al. Pleistocene Rewilding: An Optimistic Agenda for Twenty-First Century Conservation. The American Naturalist 2006. 168:5, 660-681

5 W.J. Ripple, R.L. Beschta. Trophic cascades in Yellowstone: The first 15 years after wolf reintroduction. Biological Conservation 2012. 205-213

6 David Quammen, A Canção do Dodô (Companhia das Letras, 2008).
} 
morros e florestas separados da área urbana apenas por uma rua, na qual é depositado o lixo em grandes caçambas. Atraídos pelos restos de comida, todas as noites alguns ursos descem das florestas para revirar o lixo em busca de comida. Esse hábito se tornou um espetáculo para a população local que passou a fazer questão de deixar as lixeiras abertas, mesmo após esforços do governo de mantê-las fechadas. O autor conta que todas as noites uma pequena multidão se reúne para ver esse espetáculo, sentindo muito orgulho de ter esses ursos tão perto. Nesse momento, as preocupações cotidianas não importam mais, pois a pequena janela que a aparição dos ursos abre para a natureza é simplesmente importante demais para os habitantes do condomínio.

Esse texto traz uma reflexão profunda e revela uma esperança maior do que a que é gerada por ações baseadas em razões utilitárias. Fernandez mostra que a natureza ainda está fortemente presente na essência do comportamento humano. Ela continua sendo um lugar de conforto. Tê-la por perto ainda nos agrada e nos faz sentir orgulhosos. Esses motivos podem levar à uma forte esperança de que ainda há chance de não acabarmos com a natureza.

Dentre todos os textos reunidos no livro, há um que destaco- intitulado "Um caminho para a empatia" (p. 227). Neste texto, o autor conta uma história fictícia de uma família de elefantes de forma que cada vida animal é colocada no mesmo nível de importância de uma vida humana. A história é contada de tal forma que nos leva a dar a mesma relevância que daríamos à qualquer história de vida humana. Esse texto nos desperta empatia em relação às vidas não humanas e sugere que a importância da natureza é, sobretudo, intrínseca.

A leitura deste livro de Fernandez nos leva a mudar de pensamento no que diz respeito à relação da humanidade com o meio ambiente, pois mostra as nossas falhas nessa relação, causadas pela dinâmica do mundo moderno. Mostra também o sentido pelo qual podemos seguir para tornar essa relação mais saudável. Fernandez sustenta que a empatia em relação à natureza, juntamente com a percepção da importância intrínseca dela, está presente na essência humana. Esse seria o grande e verdadeiro caminho da conservação. Muito mais do que esgotamento de recursos, as crises 
sociais e as perdas genéticas, a causa da preservação da natureza está simplesmente dentro de nós.

Afortunadamente, o livro não tem um público específico. Devido à sua linguagem informal e fluida, não é necessário ser um especialista da área do meio ambiente para ler o livro. Qualquer um que tenha interesse nos assuntos ligados à natureza e à sua conservação pode lê-lo facilmente com proveito.

\section{REFERENCIAS}

C. Josh Donlan, Joel Berger, Carl E. Bock, Jane H. Bock, David A. Burney, James A. Estes, Dave Foreman, Paul S. Martin, Gary W. Roemer, Felisa A. Smith, Michael E. Soulé, e Harry W. Greene. Pleistocene Rewilding: An Optimistic Agenda for TwentyFirst Century Conservation. The American Naturalist 2006. 168:5, 660-681

David Quammen, A Canção do Dodô (Companhia das Letras, 2008).

Fernando Fernandez, O Poema Imperfeito Crônicas de Biologia, Conservação da Natureza e Seus Heróis (UFPR, 2011).

Paul R. Ehrlich, The Population Bomb (Buccaneer Books, 1995)

W.J. Ripple, R.L. Beschta. Trophic cascades in Yellowstone: The first 15 years after wolf reintroduction. Biological Conservation 2012. 205-2 